Jurnal Scripta Teologi dan Pelayanan Kontekstual
ISSN 2086-5368 (Print)
ISSN
Http://ejournal.stte.ac.id
Vol.3, No.2, pp. 153-171, 2018

\title{
Konsep Penginjilan Dalam Kisah Para Rasul 18:9-10 Sebagai Upaya Revitalisasi Penginjilan
}

\author{
Aris Elisa Tembay
}

STT Ebenhaezer Tanjung Enim, Aristembay@gmail.com

\section{INFO ARTIKEL}

Sejarah Artikel: Diterima : 02 Nov 2018 Direvisi : o9 Nov 2018 Disetujui : 17 Nov 2018 Dipublikasi : 28 Nov 2018

\section{Kata Kunci:}

keyword one, keyword two, keyword three.

Keywords:

keyword one, keyword two, keyword three.

\section{ABSTRAK}

Salah satu tugas gereja dan orang percaya adalah pekerjaan misi. Misi adalah semua kegiatan yang bertujuan untuk mengabarkan kematian dan kebangkitan Yesus Kristus sebagai pengorbanan untuk penebusan dosa manusia serta jaminan hidup yang kekal dalam namaNya. Jadi pekerjaan misi adalah Pengabaran Injil/penginjilan.Selanjutnya gereja bukan hanya mempunyai misi, tetapi seluruh kehidupan gereja itu adalah misi. Tugas memberitakan Injil adalah tugas setiap orang percaya. Gereja yang kuat dan bersinar adalah gereja yang bersedia pergi memberitakan kasih Allah kepada dunia, sehingga dunia mengalami kasih Allah. Sehingga masa depan dunia ada ditangan gereja. Gereja haruslah memiliki hati Allah. Tugas gereja memuridkan dan mengutus para murid untuk melaksanakan Mandat Agung Kristus. Maka, memberitakan kabar baik segala perbuatan dan karya Allah adalah tugas semua orang yang telah menerima anugerah keselamatan. Benih Injil haruslah terpancar dari semua aspek kehidupan orang percaya. Gereja yang kuat dan bertumbuh adalah gereja yang terlibat dalam pelaksanaan misi Allah bagi dunia.

\section{ABSTRACT}

One of the tasks of the church and believers is missionary work. Mission is all activities aimed at proclaiming the death and resurrection of Jesus Christ as a sacrifice for the atonement of human sins and the guarantee of eternal life in His name. So missionary work is evangelism / evangelism. Furthermore, the church does not only have a mission, but the whole life of the church is a mission. The task of preaching the gospel is the duty of every believer. A strong and shining church is a church that is willing to go to preach God's love to the world, so that the world experiences God's love. So that the future of the world is in the hands of the church. The church must have the heart of God. The task of the church is to make disciples and send disciples to carry out the Great Mandate of Christ. So, to preach the good news of all the deeds and works of God is the duty of all those who have received the gift of salvation. The seeds of the gospel must be emanated from all aspects of a believer's life. A strong and growing church is a church that is involved in carrying out God's mission for the world. 


\section{Pendahuluan}

Salah satu tugas gereja dan orang percaya adalah pekerjaan misi. Misi adalah semua kegiatan yang bertujuan untuk mengabarkan kematian dan kebangkitan Yesus Kristus sebagai pengorbanan untuk penebusan dosa manusia serta jaminan hidup yang kekal dalam nama-Nya. Jadi pekerjaan misi adalah Pengabaran Injil/penginjilan.

Selanjutnya gereja bukan hanya mempunyai misi, tetapi seluruh kehidupan gereja itu adalah misi. Oleh sebab itu bisa dikatakan bahwa jatidiri gereja adalah misi. Gereja itu baru benar-benar gereja apabila ia adalah gereja yang misioner. Orientasi gereja adalah dunia. la ada di dalam dunia dan diutus ke dalam dunia. Dunia adalah sasaran misi Allah. Jelaslah bahwa misi gereja adalah berpartisipasi dalam misi Allah yang sedang mentransformasikan seluruh alam ciptaan menuju "langit baru dan bumi baru". Oleh sebab itu gereja harus terbuka bagi perubahan dan pembaruan. Tentu bukan asal baru, atau asal perubahan, tetapi perubahan yang digerakkan oleh Roh Kudus.

Sejarah gereja memang mencatat bahwa gereja ada karena penginjilan. Ini dapat dibuktikan dari catatan-catatan yang terdapat dalam kitab Perjanjian Baru khususnya dalam kitab Kisah Para Rasul. George W. Peters menjelaskan dalam bukunya menyangkut kehidupan gereja mula-mula seperti berikut:

Kitab Kisah Para Rasul mencatat perkembangan yang cepat dari Gereja. Sekurangkurangnya terdapat empat tahap dalam penyingkapan yang terjadi secara bertahap, dan hanya setelah pasal 13 maka gambaran tentang jemaat menjadi suatu Gereja dalam arti sebenarnya.

Sehubungan dengan diatas Soetarman dalam tulisannya menguraikan pertumbuhan gereja yang semakin meningkat: dimulai dari persekutuan yang terdiri dari pengikut Yesus bertumbuh dan berkembang sedemikian melampaui batas-batas bahasa dan bangsa. Sebelum peristiwa Pentakosta jumlah mereka hanya 120 orang (Kis. 1:15). Paulus menunjukkan sekitar 500 orang yang melihat Yesus sesudah kebangkitan-Nya (1 Kor. 15:6). Ada sekitar 3000 orang yang menerima kesaksian para rasul dalam peristiwa Pentakosta (Kis. 2:41) "wajar" karena didukung oleh kuasa dan dana kaisar sesudah Konstantinus bertobat.

Menurut Werner mengatakan sangat jelas bahwa Gereja yang hidup sudah barang tentu bersaksi tentang Yesus Kristus di dunia ini. Gereja yang tidak bersaksi adalah gereja yang sudah mati, walaupun masih hidup kelihatannya. Makmur Halim mengatakan, gereja masa kini banyak yang besar dan kuat secara ekonomi, tetapi kontribusi untuk pelayanan misi begitu kecil. Kebanyakan dukungan dana hanya untuk fasilitas gereja, alat-alat musik yang canggih, dan tunjangan kepada pelayan dalam jumlah yang besar. Sedangkan untuk mendukung pelayanan misi masih tidak begitu berarti. Karena itu, masalah terbesar tugas "misi"/penginjilan di dalam gereja adalah memotivasi suatu jemaat setempat untuk menginjili orang-orang di sekitarnya.

Gereja GKPA merupakan hasil dari misi penginjilan tetapi semangat penginjilan meredup atau mati. Padahal jemaat tak perlu jauh-jauh harus pergi penginjilan ke daerah lain melainkan di sekitar mereka banyak orang-orang yang perlu diinjili atau diberitakan Kabar Baik. Pemberitaan Injil tidak terbatas pada satu tempat saja melainkan dimana perlu melaksanakan penginjilan.Gereja-gereja di tanah Batak merupakan hasil dari Penginjilan atau pelayanan para misionaris. Salah satu misionaris yang melayani di tanah Batak yaitu Ludwig Nommensen. "Rasul suku bangsa Batak" ini mulai bekerja di antara kaum Batak-Toba di lembah Silindung pada tahun 1862. Dari 
pelayanannya berdiri gereja batak yang pertama yaitu Huria Kristen Batak Protestan (HKBP). HKBP semakin meluas ke daerah Angkola sehingga berdirilah GKPA.

Yang menjadi pokok permasalahannya bagaimana memotivasi gereja/umat Tuhan dapat kembali meningkatkan keefektifan penginjilan sebagai salah satu tugasnya gereja ditengah masyarakat. Sehingga GKPA Resort Padangsidimpuan Tenggara tidak hanya bergaul dengan masyarakat yang majemuk melainkan dapat memberitakan Kabar Baik (Injil) dan tidak hanya memberikan ceramah rohani saja melainkan menjadi saksi Kristus yang benar juga dan menjadi gereja yang misioner. Dan berikut penulis memaparkan beberapa kasus yang sedang terjadi atau yang dialami baik hamba Tuhan maupun umat Tuhan yang ada di GKPA resort Padangsidimpuan Tenggara:

Sebagai contohnya kasus pertama, ada satu ibu berinisial M.P memberi penjelasan kalau hanya dengan memotivasi orang sakit dengan menyuruh untuk berdoa kepada Tuhan saja, sudah menganggap sebagai penginjilan kepada orang lain. Jadi setelah dicermati ternyata ibu M.P ini kurang memiliki pemahaman mengenai dasar dan isi dari pemberitaan Kabar Baik tersebut. Dengan kata lain, orang sakit tersebut tidak dibawa kepada pengenalan Yesus Kristus. Kasus kedua, seorang bapak berinisial E.S memberikan alasan bahwa takut kepada orang lain atau masyarakat sekitarnya yang fanatik. Sehingga bapak ini takut untuk melaksanakan penginjilan. Kasus ketiga H.R inisial dari seorang bapak memberikan keterangan bahwa penginjilan sangat berat dan susah diterapkan dilingkungan yang non-Kristen yang sangat fanatik. Selanjutnya seorang ibu berinisial D.P mengemukakan pendapat bahwa masalah di dalam penginjilan oleh karena kurang motivasi dari orang lain dan dukungan dana di dalam pelayanan penginjilan tersebut.

Berdasarkan dari uraian masalah yang diatas, maka penulis terdorong untuk menulis journal dengan judul "Konsep Penginjilan Dalam Kisah Para Rasul 18: 9-10 Sebagai Upaya Revitalisasi Penginjilan Di GKPA se-Resort Padangsidimpuan Tenggara. Harapan penulis, hamba dan Umat Tuhan/Jemaat GKPA se-Resort Padangsidimpuan Tenggara dapat aktif melayani baik di dalam gereja maupun diluar gereja (Penginjilan). Setelah memahami Kisah Para Rasul 18:9-10 dapat terdorong, termotivasi dan bersemangat untuk penginjilan. Sehingga banyak orang yang mendengarkan Injil dan percaya kepada Kristus.

\section{Metode Penelitian}

Dalam penulisan ini penulis menggunakan metode deskriftif-bibliologis. Metode deskriftif adalah suatu metode penelitian yang meneliti sekelompok manusia, suatu objek, suatu kondisi, suatu sistem pemikiran ataupun suatu kilas peristiwa masa sekarang. Ada pun tujuan penelitian ini adalah untuk memuat deskripsi, gambaran atau lukisan secara sistematis, faktual dan akurat mengenai fakta-fakta, sifat-sifat serta hubungan antar fenomena yang diteliti.

Selain itu tujuan dari penelitian ini untuk mengumpulkan data, gambaran, penegasan suatu konteks atau gejala serta sesuatu pertanyaan hubungan dengan status subjek penelitian saat ini. Pengumpulan data dilakukan dengan cara penelitian, menganalisis literatur dan untuk mendapatkan data yang lebih lengkap. Maka penulis juga menggunakan instrumen berupa wawancara. 
Hasil Dan Pembahasan

Konsep Penginjilan Dalam Kisah Para Rasul 18:9-10

Analisa Kitab Kisah Para Rasul

SeorangahliPerjanjianBaruPhilip Johnston menjelaskan dalam bukunya IVP Introduction To The BIBLE,

Kisah Para Rasul menjelaskanbahwaYesus sungguh-sungguh adalah Mesias, seperti yang diteguhkan dengan tanda-tanda ajaib yang Allah lakukan melalui Dia (2:22; 9:22).Pengabaran Injil kepada orang bukan Yahudi juga dinubuatkan dalam Alkitab sebagai bagian dari keselamatan Allah pada akhir zaman. Hal itu bukan diprakarsai oleh manusia, melainkan oleh Allah sendiri (10-11:8; 13:47; 15:1-29; 28:2829). Paulus dari Tarsus - rasul bagi orang bukan-Yahudi - bukanlah seorang Yahudi murtad yang berkhotbah melawan tradisi Yudaisme, melainkan merupakan alat Allah yang setia untuk membawa keselamatan kepada orang-orang bukan-Yahudi (9:15-16; 13:46-48; 19:35-41; 22:21; 26:20).

Lukas berusaha menunjukkan bahwa orang-orang Kristen seperti Paulus bukanlah orang-orang upahan dan pembuat huru hara, melainkan warga negara yang patuh hukum yang membawa berita pengharapan dan keselamatan bagi dunia (16:37$40 ; 18: 12-15 ; 19: 35-41 ; 22: 22-29 ; 23: 27-30 ; 24-28)$.

\section{Penulis Kisah Para Rasul}

Kisah Para Rasul bukanlah suatu unit tersendiri, karena jelas bahwa kitab ini ditulis sebagai kelanjutan dari Injil Lukas. Tradisi yang tertua juga dengan suara bulat menunjuk kepada Lukas sebagai penulisnya. Senada dengan itu, J. Sidlow Baxter memberikan empat alasan yaitu:

Pertama, kitab Kisah Para Rasul dan Injil Lukas, keduanya ditujukan kepada Teofilus (Luk. 1:1; Kis. 1:1), dan pada permulaan Kisah Para Rasul, penulis mengingatkan Teofilus akan karangannya yang pertama yaitu Injil Lukas. Kedua, para ahli sependapat bahwa kedua kitab itu terdapat persamaan: ungkapanungkapan, gaya bahasa dan cara penyajian ceritanya, terutama mengenai istilah medis yang patut dipakai oleh "tabib Lukas yang kekasih" (Kol. 4:14).

Maka dengan demikian dapat disimpulkan bahwa penulis kitab Kisah Para Rasul adalah Lukas.

\section{Pribadi Penulis dan Waktu Penulisan}

Dalam Kol. 4:14 dicatat bahwa Lukas adalah seorang tabib. Sumber yang lainnya juga mengatakan bahwa Lukas adalah seorang tabib, dan menurut tradisi pada abad ke-2, ia berasal dari Antiokhia di Siria. Philip Johnston mengatakan bahwa Lukas adalah tabib dan misionaris (pengabar Injil) pada waktu bersama rasul Paulus (Kol. 4: 4; 2Tim. 4: 11; Flm. 1: 24), dan Kol. 4: 11-14 menjelaskan bahwa Lukas adalah seorang bukan Yahudi. Hal ini didukung oleh bukti internal dari tulisan-tulisan Lukas sendiri, bahwa ia adalah satu-satunya penulis dari kalangan bukan Yahudi di antara penulis-penulis kitab Perjanjian Baru.

Kapan Kisah Para Rasul ditulis tidaklah diketahui pasti. Beberapa pakar meyakini bahwa Lukas menyelesaikan tulisannya sebelum Paulus dibebaskan, dan kemudian mati syahid. Itu berarti kitab ini ditulis sekitar tahun 60-62 M. Injlil Lukas mungkin ditulis saat sebelum Kisah Para Rasul mungkin pada akhir 50-an Masehi. MenurutOla Tulluan bahwa kitab Kisah Para Rasul ditulis kira-kira tahun 62-63 M. Karena peristiwa 
terakhir yang dilaporkan Lukas adalah tentang keadaan rasul Paulus dalam penjara di Roma. Kemudian senada dengan itu J. Sidlow Baxter memperkirakan bahwa kitab Kisah Para Rasul ditulis sekitar tahun $63 \mathrm{M}$.

David J. Williams berpendapat bahwa "tidak ada seorangpun yang tahu dimana kitab Kisah Para Rasul ditulis, namun apabila dicermati dari bahasa penulis yang sangat dipengaruhi oleh budaya Hellenistic, maka dapat diperkirakan kitab Kisah Para Rasul ditulis di kota Roma. Sehubungan dengan itu juga, Yune Sun Park mengatakan bahwa menurut tradisi sesudah Jerome, kitab Kisah Para Rasul ditulis di Roma. Dengan demikian penulis menyetujui bahwa kitab Kisah Para Rasul ditulis di kota Roma.

\section{Panggilan Paulus Untuk Melayani}

Pada usia kira-kira 30 tahun diperkirakan Paulus sudah menerima mandat sebagai pemimpin penganiaya orang Kristen. Kejadian terbesar yang dialami oleh Paulus dalam perjalanan ke Damsyik, merupakan titik awal bagi Paulus untuk mengalami pertobatan. Perjumpaan Saulus dengan Tuhan Yesus merupakan perjumpaan yang Ilahi.Melalui perjumpaan tersebut, telah mengubah segala-galanya di dalam diri Saulus, baik pendiriannya, konsepnya terhadap kehendak Tuhan, bahkan juga menjadi panggilan bagi Saulus untuk melayani Tuhan Yesus.

Perjumpaan Paulus dengan Yesus Kristus memulai hidup baru bagi Paulus. Perjumpaan dengan Yesus secara langsung meyakinkan nalar dan nuraninya tentang kenyataan kebangkitan-Nya. George Eldon Ladd dalam bukunya menjelaskan bahwa perubahan total pandangan Paulus ini tidak terjadi berangsur-angsur melalui pengkajian, penyelidikan, perenungan, perdebatan, dan argumentasi, melainkan terjadi secara sekejap melalui pengalamannya dalam perjalanan ke Damsyik.

\section{Misi Pelayanan Paulus Dalam Kisah Para Rasul 18:9-11}

Paulus tidak lama tinggal di Atena. Mungkin di kota Atena itu tidak banyak yang ingin mendengar Injil, sehingga Paulus mengambil keputusan untuk pergi ke kota Korintus. Sampai di Korintus Paulus masih belum dihubungi dengan Silas dan Timotius (pasal 17:15). Harrison menjelaskan bahwa penjelasan ini bahwa Paulus melaksanakan tugasnya pada hari Sabat melayani terhadap orang-orang Yahudi dan orang-orang Yunani.

Mula-mula ia berbicara kepada orang-orang Yahudi, tetapi tatkala mereka memusuhi serta menghujat dia, sehingga ia pergi kepada bangsa-bangsa lain. Ketika itu Paulus menumpang di rumah Titius Yustus, seorang "yang beribadah kepada Allah." Rumahnya berdampingan dengan rumah ibadat. Yustus membuka rumahnya untuk dipakai Paulus sebagai tempat pertemuan. Tempat ini lebih mudah didatangi oleh orang-orang bukan Yahudi, dan karena dekat rumah ibadah, maka orang-orang Yahudi dapat hadir juga. Bukan hanya orang Yahudi saja fokus pelayanan Paulus melainkan orang-orang Yunani yang ada di Korintus. Ayat 8 "... banyak dari orang-orang Korintus" mungkin mereka adalah orang-orang Yunani, sebab jika kita baca I Korintus, kebanyakan jemaat Korintus adalah orang-orang Yunani (1Kor. 1:22).

\section{Konteks Sebelum Kisah Para Rasul 18:9-10}

Pasal 18:9-10 sangat berkaitan dengan ayat-ayat sebelumnya. Pasal 18:1 mengisahkan dimana setelah dari Atena, Paulus berangkat ke Kota Korintus. Di kota Korintus akan dimulailah suatu masa kerja yang sangat penting dan baru bagi Paulus. 
Seperti di Atena, Paulus mula-mula hanya sendirian (ayat 1-4). Barulah kemudian, Timotius dan Silas datang kepadanya (ayat 5). Tetapi Allah segera mempertemukannya dengan sepasang suami isteri yaitu Akwila dan Priskila, yang akan menjadi temanteman sekerja yang setia. Paulus memberitakan dengan tekun dan sungguh - sungguh bahwa Yesus adalah Mesias (ayat 5).

Pada ayat 8 kepala rumah ibadat bertobat dan percaya lalu seisi rumah Krispus ikut percaya dan dibaptis, membuat orang Yahudi semakin tak menyukai Paulus dan akhirnya menghujat Namun demikian, Paulus tidak meninggalkan kota Korintus meskipun ada penganiayaan, karena banyak orang seperti ini akan menjadi percaya kepada Tuhan. Hal itu terjadi oleh karena pimpinan dari Roh Kudus.

\section{Konteks Sesudah Kisah Para Rasul 18:9-10}

Pada ayat 11 dijelaskan bahwa Paulus bekerja paling sedikit satu setengah tahun di Korintus. Lama orang-orang Yahudi membiarkan keadaan itu berlangsung terus, tetapi ketika datang seorang wali negeri yang baru dan mereka menyangka dapat mengharapkan pertolongan daripadanya, mereka pun mengadakan aksi bersama melawan Paulus. Galio tidak memberi kesempatan sesaat pun kepada Paulus untuk berbicara. Agaknya ia cukup mengenal orang-orang Yahudi dan tidak mau diperalat oleh mereka. Perkataan Galio diutarakan di depan orang Yahudi menunjukkan bahwa ia telah mengerti pokok perselisihan (ayat 13) di antara Paulus dan orang Yahudi. Orang-orang Yahudi menyangkal kesaksian keagamaan Paulus. Dengan demikian hakim-hakim Romawi biasanya tidak ingin campur tangan atas hal-hal yang berhubungan dengan hukum Taurat karena hal itu berkaitan dengan agama.

\section{Uraian Eksegetis Kisah Para Rasul 18:9-10}

Dalam teks Kisah Para Rasul 18:9-10 diawali dengan suatu penglihatan. Istilah ini menunjukkan suatu peristiwa yang gaib ketika Allah menyatakan diri kepada seseorang (lihat 7:31 dan 9:10). Selanjutnya, penulis akan menguraikan dan menjelaskan dalam bentuk eksegese dari teks Kisah Para Rasul 18:9-10 sebagai berikut:

\section{Jangan takut}

Kata "jangan takut" dalam bahasa Yunani memakai kata Mì фoßoû. Mì particle negative from $\mu \eta$, yang artinya tidak, jangan, supaya jangan, apakah, mungkin, jangan lagi. Terjemahan dalam kamus Yunani-Indonesia mengartikan mh,yaitu tidak, jangan (biasanya dipakai dengan kata keterangan bukan indikatif, atau dengan bentuk kata keterangan Imperatif, Infinitif, Subjungtif, partisip, optatif ). Partikel ingkar mh,akan dipergunakan dan berarti melarang dilanjutkan-nya suatu tindakan yang sedang berlangsung.

Kata "takut" dalam bahasa Yunani ditulis dengan kata фoßou/ verb imperative present middle 2nd person singular from $\phi о \beta^{\prime} \epsilon \omega$. Presen imperatif menyatakan tindakan yang tengah berlangsung atau bentuk kata kerja perintah yang sedang disampaikan atau berlangsung. Middle disini dimaksudkan bahwa subjek bertindak sebagai pelaku tindakan dan sekaligus juga sebagai penderita. Dalam ayat 9 ini Paulus yang menjadi subjek yang bertindak sebagai pelaku dan sekaligus sebagai penderita yang mengalami ketakutan. Orang kedua tunggal menunjuk kepada Paulus.

Dalam Kamus Besar Bahasa Indonesia, kata "takut" diartikan: merasa gentar (ngeri) menghadapi sesuatu yg dianggap akan mendatangkan bencana;) tidak berani 
(berbuat, menempuh, menderita, khawatir. Afraid sesuatu yang belum pasti dikuatirkan dan bahkan yang tak menyenangkan atau berbahaya yang akan terjadi.

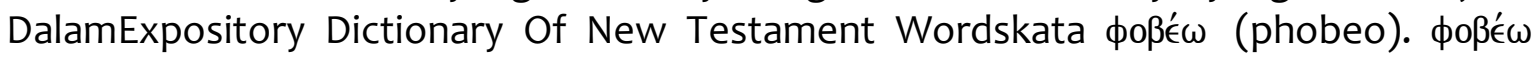
(phobeo) yang dimaksudkan disini suatu tindakan yang pasif menunjuk kepada ketakutan.

Senada dengan di atas, Yune Sun Park menafsirkan kata "jangan takut" (Mì $\phi о ß о u) ~ a d a l a h$ kosakata sekarang, yang berarti bukan melarang takut sesaat karena suatu kejadian yang terjadi, tetapi hidup terus menerus tanpa ketakutan.

Jadi, kata "jangan takut" merupakan suatu kalimat perintah atau keinginan /harapan yang bersifat larangan dari Tuhan yang disampaikan kepada Paulus agar Paulus tidak terus-menerus merasa ketakutan melainkan menghentikan rasa takutnya, rasa kuatirnya itu atau tidak gentar lagi untuk menghadapi sesuatu yang dianggap mendatangkan bencana. Namun dalam konteks ini, Paulus menghadapi orang orang Yahudi yang menghujat dia di dalam pelayanannya. Kata "jangan takut" dalam ayat ini menunjukkan bahwa Tuhan memberi penghiburan yang amat besar kepada Paulus, dan menunjukkan keinginan/harapan Tuhan dalam bentuk perintah bagi Paulus bertujuan agar kembali untuk memperkatakan Injil dengan berani dan sepenuhnya. Tuhan menginginkan Paulus berhenti merasa takut atau dengan kata lain Paulus diperintahkan atau didorong untuk menghentikan rasa takutnya itu dan kembali untuk melaksanakan tugas dan tanggung jawabnya sebagaimana mestinya di dalam pemberitaan Firman/Injil.

\section{Teruslah Memberitakan Firman}

Kata "teruslah memberitakan firman" ditulis dalam bahasa Yunani $\dot{\alpha} \lambda \lambda \dot{\alpha} \lambda \dot{\alpha} \lambda \epsilon \mathrm{l}$. Di dalam teks aslinya memakai $\dot{\alpha} \lambda \lambda \alpha$ (alla) yang artinya tetapi atau melainkan (penghubung intra-kalimat untuk menyatakan hal yang bertentangan atau tidak selaras). Sementarala, $\lambda \in \iota$ (lalei) dalam bentuk verb 2nd person singular present active imperative dari kata dasar $\lambda \alpha \lambda \epsilon^{\prime} \omega$ (laleo) ditulis sebanyak 296 kali, artinya bersuara, mengucapkan, berkata, menyebutkan, menyatakan, memberitakan, melaporkan, membisikkan. Kata $\lambda \alpha^{\prime} \lambda \epsilon \iota$ (lalei) berbentuk kata kerja orang kedua tunggal presen aktif perintah. Kata kerja orang kedua tunggal mengarah kepada Paulus, presen disini untuk menunjukkan bahwa suatu pekerjaan sedang dilakukan atau dilakukan berulang kali (terus-menerus) dalam waktu kini atau di kemudian hari pasti terjadi. Maka dengan demikian, Paulus sebagai subjek menjadi pelaku yang bertindak untuk menyatakan, memberitakan atau mengucapkan firman secara aktif, dan yang dilakukan berulang kali atau terus menerus dalam waktu kini atau di kemudian hari di dalam pemberitaan pasti dilakukan.

Demikian juga Horst Balz and Gerhard Schneider menerjemahkan $\lambda \alpha \lambda \epsilon ́ \omega$ mengatakan, membicarakan. Di dalam Perjanjian Baru $\lambda \alpha \lambda \lambda^{\prime} \epsilon \omega$ hanya ditemukan dengan arti mengatakan, membicarakan/berbicara, yang dimana ada perbedaan sedikit keterampilan untuk berbicara yang khas pada beberapa bagian. Seperti $\lambda \varepsilon \gamma \omega$ (lego), $\lambda \alpha \lambda \lambda^{\prime} \omega$ (laleo)dapat menjadi kata kerja transitif (keterangan pelengkap) misalnya "aku mengatakan kebenaran" (Yoh. 8:40 sinonimnya dalam ayat 45). Sehingga $\lambda \alpha \lambda \epsilon^{\prime} \omega$ (laleo) menceritakan atau mengatakan yang berisi kebenaran atau firman Allah.

Pengertian yang pararel di dalam National America Standard (NAS) kata "memberitakan" diterjemahkan but go on speaking yang artinya tetapi meneruskan berbicara/ berpidato. Sementara di dalam New International Version (NIV) 
ditulis keep on speaking yang artinya melanjutkanberbicara. Sementara King James Version (KJV) menerjemahkan dengan kata but speak yang artinya tetapi katakanlah. Maka dengan demikian kata "memberitakan" dalam ayat ini mengacu kepada Paulus untuk kembali meneruskan, melanjutkan ataupun memperkatakan firman kepada orang-orang Yahudi dan di sekitarnya pada waktu itu.

Dari uraian diatas dapat disimpulkan kata "teruslah memberitakan firman" bahwa Paulus sebelumnya adalah pemberita Injil yang aktif. Dimanapun Paulus berada, Injil yang terus disampaikan atau menjadi isi pemberitaannya. Namun, sebelum ayat ini Paulus menghadapi tantangan yang membuat dirinya kurang aktif untuk memperkatakan Firman (Injil). Maka dalam ayat ini, Paulus diberi perintah oleh Tuhan untuk kembali secara aktif melanjutkan yang telah dikerjakan sebelumnya yaitu memberitakan Injil.

\section{Dan jangan diam}

Istilah "dan" dalam bahasa Yunani ditulis dengan kata кai (kai) yang artinya dan, juga, bahkan, dan khususnya, memang, bahwa, yaitu, ketika, maka, adapun, demikian juga, demikian,sehingga, malah, namun, walaupun, padahal, kemudian, lalu, karena, bukan saja ... tetapi juga, atau, dari. Kata "kai" ditulis sebanyak 9037 kali. "Kai" berbentuk kata cunjuntion coordinating correlative yang artinya kata ini digunakan untuk menunjuk pada suatu kesinambungan yang sederajat dari kalimat yang sebelumnya.

Dan kemudian dilanjutkan dengan kata "jangan". Kata "jangan" pada kalimat ini artinya sama dengan kata "jangan" dalam kalimat "jangan takut."Maka, penulis

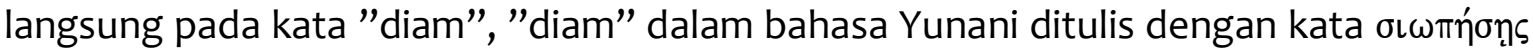
dalam bentuk verb 2nd person singular aorist active subjunctive from $\sigma \iota \omega \pi \alpha \dot{\omega} \omega$. Kata kerja subjungtif aorist aktif orang kedua tunggal dari kata " $\sigma \omega \omega \pi \alpha \omega \omega$ (siopao), yang artinya diam, berhenti berbicara, tidak dapat berbicara, menjadi tenang. Dan ditulis sebanyak 10 kali. Subjungtif untuk menegaskan suatu tindakan yang belum pasti. Aorist untuk menyatakan bahwa suatu hal pernah terjadi atau pernah dilakukan. Aktif menunjuk kepada subjek bertindak sebagai pelaku tindakan. Artinya dalam ayat ini Paulus pernah secara aktif bertindak diam, secara mutlak menegaskan tindakan diam Paulus sekali berlangsung pada masa lampau. Sebab dalam jenis ini tindakan untuk subjungtif aoris bersifat belum tentu.

Sehubungan dengan di atas, James Strong menjelaskan kata "diam" dengan arti diam, hening, kebisuan, keheningan tanpa sengaja, atau mendiamkan, atau ketidakmampuan untuk berbicara, dan dengan demikian berbeda dari "Sige", yaitu yang mana agak ada penolakan yang disengaja atau keengganan untuk berbicara, walau peristilahan ini sering memakai yang searti; yang bisu (tetapi tidak tuli), yang tenang (sebagai air tenang). Dan kata ini ditulis sebanyak 11 kali. Williammenjelaskan kata "diam" dengan kataterus diam, tidak ada kata, berusaha tidak bersuara Mat. 26:63, berhenti berpidato, jadi atau menjadi diam.

Barclay menjelaskan kata siopao dengan arti diam, tidak berbunyi; berhenti bicara; menjadi tenang (laut). Sehubungan dengan itu, Friberg di dalam Analytical Greek Lexicon mejelaskan kata siopao dalam bentuk impferpek $\epsilon \sigma \iota \omega \dot{\pi} \pi \nu$ (esiopon);

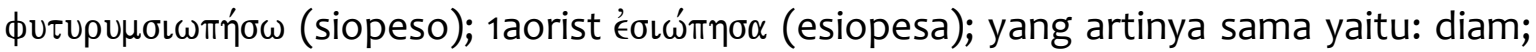
(1) jadi diam, jangan buat bunyi, diam (Mrk. 3:4); (2) menjadi diam, (a) seseorang berhenti berbicara, menjadi diam (Mat. 20:31); (b) ibarat, angin reda dan ombak diam, 
menjadi tenang (Mrk. 4:39); (3) jadi bisu, tak dapat berbicara (Luk. 1:20). Jika demikian maka kata "diam" merupakan tindakan yang disengaja untuk tidak berbuat apa-apa atau tidak ada perkataan yang disampaikan.

Dengan demikian dapat disimpulkan bahwa kata "dan jangan diam" merupakan lanjutan dari perkataan Tuhan kepada Paulus yang memberikan penegasan bahwa Paulus harus menghentikan tindakan yang berdiam diri atau tidak boleh sama sekali tidak memberitakan Injil tetapi harus melanjutkan memperkatakan firman seperti yang sudah dilakukan sebelumnya.

\section{Sebab Aku menyertai engkau}

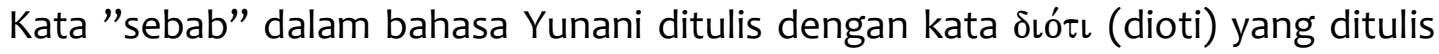

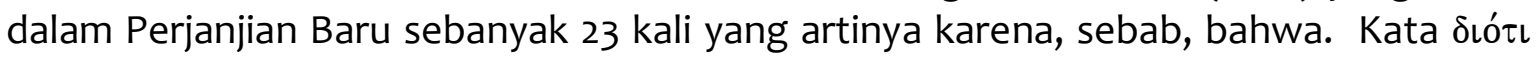
(dioti) ditulis dalam bentuk conjunction subordinating causal yaitu kata penghubung (antara kalimat pokok kalimat dan anak kalimat) bersifat sebab-menyebab.

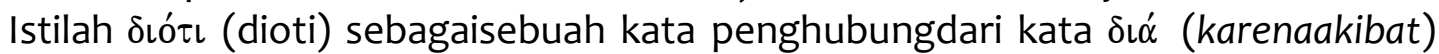

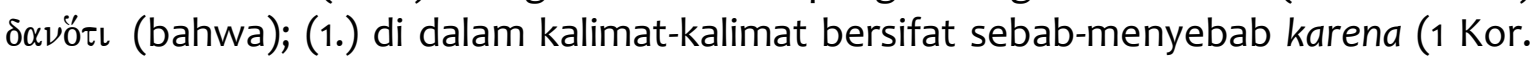
15:9; mungkin Rm. 8:21); (2.) untuk memperkenalkan satu kalimat yang dapat disimpulkan oleh sebab itu(Kis. 13:35); (3.) sebagai padanan ke kata penghubung sebab

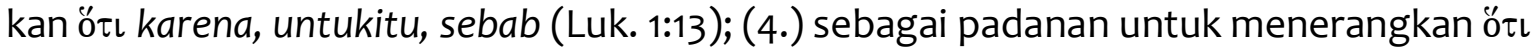
bahwa (mungkin Rm. 8:21 ). Dalam kamus oxford kata "for" (sebab) yang artinya digunakan untuk pendahuluan alasan dari sesuatu sebutan di dalam penyataan sebelumnya. Dalam Kamus Besar Bahasa Indonesia kata "sebab" tersebut diartikan sebagai hal yang menjadi timbulnya sesuatu; lantaran; karena; (asal) mula; oleh karena.

Istilah "' $\gamma \omega$ " (ego) merupakan kata ganti orang pertama tunggal, artinya "Aku." Kata "' $\gamma \omega$ " (ego) ini mengacu pada Tuhan. Dalam ayat 9 ini, kata " $€ \gamma \omega$ " (ego) berlaku sebagai nominative. Artinya, Tuhan merupakan subyek dari kalimat tersebut. Sebagai nominative, jikakata "' $\gamma \omega$ " (ego) bergabung dengan verb (kata kerja), maka pada umumnya pengertiannya menyatakan kesungguhan atau penekanan khusus.

Dalam ayat ini, kata $\epsilon i \mu \iota$ (eimi) ditulis dalam bentuk kata kerja orang pertama tunggal present aktif indikatif artinya bahwa kata eílı menunjukkan suatu kepastian atau menunjukkan suatu tindakan yang benar-benar terjadi dari orang pertama (menunjuk pada subjek yang hidup) sehingga artinya adalah "sedang ada". Oleh

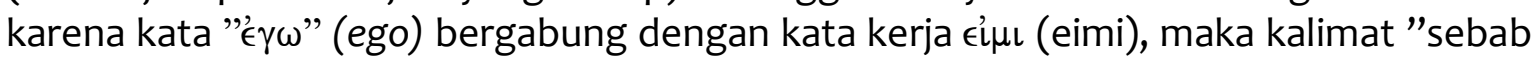
Aku sedang ada atau sebab Aku ada." Maka kata "evgweivmi" menunjuk kepada kesungguhan keberadaan Tuhan di dalam penggenapan atau pelaksanaan perintahNya.

Senada dengan di atas,Spiros menjelaskan kata $\mu \in \tau \dot{\alpha}$ (meta) dengan kata depan yang dengan genetif dan akusatif. Kata $\mu \in \tau \dot{\alpha}$ (meta) ini pengertian utamanya adalah pertengahan, ditengah-tengah, pada tengah-tengah, dengan, di antara, menyatakan secara tidak langsung menyertai dan demikian membedakan darisunbersama-sama dengan, suatu penghubung perpaduan perasaan. Dengan genetif berarti sedang menyatakan secara tidak langsung perkawanan, persahabatan.

Jadi, sesuai dengan uraian di atas kata "Sebab Aku menyertai engkau" menekankan kesungguhan Tuhan terhadap perkataan-Nya. Tuhan sesungguhnya tidak membiarkan Paulus menjalankan perintah-Nya sendirian dan bahkan sebaliknya Tuhan menyatakan Paulus dipihak-Nya. Tuhan menginginkan Paulus untuk melangkah dengan 
penuh keyakinan dan kepastian di dalam mengajarkan, mengatakan, menyampaikan firman bagi orang-orang Korintus.

\section{Percayalah tidak ada seorangpun yang akan menjamah dan menganiaya engkau}

Istilah "dan tidak ada seorang pun yang akan menjamah dan menganiaya engkau"

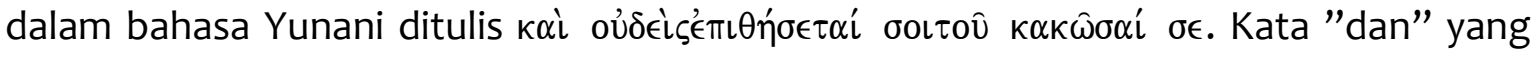
mengawali kalimat dalam ayat ini dalam bahasa Yunani $\kappa \alpha \iota$ dalam bentuk yang sama dengan kata "dan" pada kalimat "dan jangan diam". Kata "tidak seorang pun" dalam bahasa Yunani ditulis oủঠeis adjective nominative masculine singular no degree from oủói $\varsigma$ berbentuk kata sifat nominatif maskulin tunggal tidak ada gelar. Yang artinya subjek/orang disebutkan yang mempunyai kekuatan namun tidak memiliki penjelasan yang lengkap. Friberg menjelaskan kata oủóí menunjuk kepada ketiadaan, ketidak adanya sesuatu atau seseorang bahkan sesuatu apapun tidak ada baik sebagai kata sifat, kata benda dan sebagai akusatip mengarah pada pengertian tersebut.

Jadi, dengan demikian dari uraian di atas kata "tidak seorang pun" menyatakan Tuhan memberikan janji/jaminan keamanan di dalam pelayanannya. Sehingga Paulus tidak perlu kuatir berlebihan terhadap orang-orang Yahudi atau siapapun yang berada di Korintus yang menghujat ataupun yang menghambat pelayanannya dan bahkan mengancam keberadaannya. Dengan perkataan ini Paulus dapat bersemangat melayani Tuhan dan leluasa untuk memberitakan firman.

\section{Janji Penyertaan Tuhan}

\section{Tidak ada yang menjamah}

Kata "menjamah" dalam bahasa Yunani adalah '€mı $\theta \dot{\eta} \sigma \in \tau \alpha \iota$ (epithesetai). National America Standard menerjemahkan dengan menggunakan kata will attackyang berarti menuju kepada seseorang yang memiliki hasrat untuk menyerang dan New International Version menggunakan kata going to yang berarti bermaksud menyerang "attack". Dan di dalam King James Version menggunakan kata shall set on yang artinya akan menyerang. Kata $€ \epsilon \iota \theta \dot{\eta} \sigma \in \tau \alpha \iota$ (epithesetai) tersebut ditulis dalam bentukverb 3 rd person singular future middle indicative dari $\kappa \alpha \tau \alpha^{\prime} \in \pi \iota \tau i \theta \eta \mu \iota$ (epitithemi) yang artinya meletakkan, memberi, menambahkan, menyerang. Kata ini ditulis sebanyak 39 kali. Dalam Exegetical Dictionary Of The New Testament kata "yang akan menjamah" yang dalam bahasa Yunanievpiqh,setai,dijelaskan dengan menggunakan kata yang berbentuk mideal Attack (menyerang), touch (menyentuh) (Kis 18:10). Vine menjelaskan Epitithemi bahwa orang Yahudi memiliki niat akan menyerang Paulus.

Kittel menjelaskan istilah $\varepsilon \pi \iota \imath \Theta \eta \mu \iota$ (epitithemi) dengan bentuk mideal dapat berarti"untuk meletakkan"helm (perlindungan kepala), "untukb mendiskusikan" persoalan, "untuk membuat sebuah gempuran pada," "untuk mencegat."Untuk meletakkan padatangan-tangan, sementarapadaperistiwa yang lain inimempunyai pengertian bermacam-macam. Hal yang serupa di dalam The Word Study Concordance kata $\varepsilon \pi \iota \tau(\vartheta \eta \mu \iota$ (epitithemi) ditulis dengan artinya menambah sampai, memuatkan, mengenakan, membebankan, mengadakan, menyerang, menetapkan.

Maka dengan demikian kata "yang akan menjamah," pernyataan dimana seseorang memiliki niat akan melakukan tindakan untukmembuatsebuahgempuran pada diri Paulus sendiri ataupun akan menyerang diri Paulus. 


\section{Menganiaya Engkau}

Kata "menganiaya" dalam bahasa Yunani ditulis dengan kata "к $\alpha \kappa \hat{\omega} \sigma \alpha$,', ditulis dalam bentuk verb infinitive aorist active genetive. Verb infinitive aorist active adalah menyatakan suatu perbuatan yang hanya satu kali saja atau sudah selesai dibuat. Kata

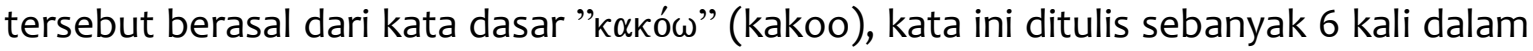
Perjanjian Baru, kata ini memiliki arti menjahati, menggusarkan. Dalam Word Study menjelaskan kata " $\kappa \alpha \kappa \omega \hat{\omega} \alpha$ '" artinya dipengaruhi, perbuatan jahat, kejahatan yang sangat serius, mencelakakan, merugikan, menyakiti hati. Jadi, Paulus mendapat perlakuan tidak baik, namun kalimat sebelumnya menunjukkan dimana Paulus mendapat arahan ataupun pernyataan untuk melaksanakan tugasnya dengan keyakinan Tuhan bersamanya, sehingga Paulus tidak perlu mengkhawatirkan orang yang ingin berbuat jahat terhadap dirinya.

Dalam Theological Dictionary Of The New Testament, како́ (kakoo) selalu diartikan "tindakan menyakiti/melukai", "menganiaya","untuk menyebabkan cedera". Arndt dan Gingrich menjelaskan "kakaoo" dengan kata mencelakakan, menganiaya kepada objek langsung. Senada dengan itu Spiros menjelaskan kata "kakoo" denganmencelakakan atau melakukan kejahatan terhadap seseorang, menganiaya, mengganggu, melukai; untuk menaruh satu ke dalam sebuah suasana hati yang tidak enak melawan yang lain. Ditulis sebanyak 6 kali. Kata " $\sigma \epsilon$ " yang dalam bentuk Noun Prounoun Accusative -second person Singular mengarah pada pribadi Paulus sebagai objek. Orang Yahudi ingin mencelakakan, melukai atau membuat cedera diri Paulus sendiri.

Jadi, kata "menganiaya engkau" menunjukkan dimana suatu perbuatan mencelakakan atau melakukan kejahatan terhadap Paulus yang dapat mengakibatkan dampak negatif dan bahkan kematian baginya. Namun, Tuhan yang ada dipihak Paulus tidak mengijinkan hal buruk yang terjadi kepada hamba-Nya. Tuhan yang memberikan tugas atau perintah pasti Tuhan juga yang akan menjamin kehidupan hamba-Nya (Paulus).

\section{Dasar Pergi Untuk Memberitakan Injil Sebab banyak umat-Ku di kota ini}

Kata "sebab banyak umat-Ku di kota ini" ditulis dalam bahasa Yunani

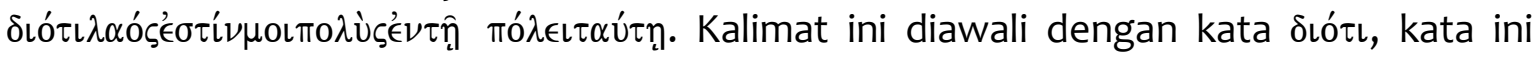
ditulis dalam $\delta$ ıó $\iota$ (dioti) sebagaisebuah kata penghubungdari kata $\delta\llcorner\alpha$ (karena akibat) dan ö ı (bahwa); (1) di dalam kalimat-kalimat bersifat sebab-menyebab karena (1 Kor. 15:9; mungkin Rm. 8:21); (2) untuk memperkenalkan satu kalimat yang dapat disimpulkan oleh sebab itu (Kis. 13:35); (3) sebagai padanan ke kata penghubung sebabkan ö ı karena, untuk itu, sebab (Luk. 1:13); (4) sebagai padanan untuk menerangkan ö $\iota$ bahwa (mungkin Rm. 8:21).

Istilah "umat-Ku" dalam bahasa Yunani ditulis dengan kata " $\lambda \alpha o ́ \varsigma$ " (laos) ditulis dalam bentuk noun masculine singular nominative ditulis 143 kali yang artinya suatu kata benda yang ditujukan kepada subjek tunggal yaitu yang bersifat jantan (laki-laki). Dalam Word Study kata " $\lambda \alpha o ́ s "$ (laos) diterjemahkan dengan kata people, jika dalam bentuk kata benda maka diartikan orang-orang, rakyat, bangsa. Senada dengan itu, dalam Strong's menjelaskan kata "lao,j" (laos) dengan apparent a primary word; a people (in gen; thus differing; which denotes one's own populace):-people. 
Alexander Crude menjelaskan dalam bukunya bahwa dalam kasus ini terdapat lebih jelas lagi gagasan atau gambaran mengenai bangsa-bangsa atau dari orang banyak berkumpul bersama-sama. Di dalam Perjanjian Baru bentuk tunggal jadi lebih sering diubahkan ke bentuk jamak. Vine menjelaskan People dari kata $\lambda \alpha o ́ s$ (laos) digunakan untuk (a) orang-orang bebas, terutama dari orang banyak berkumpul; (b) seorang dari ras/bangsa dan bahasayang sama; (c) orang-orang Kristen sebagai orangorang dari Tuhan.

Sehubungan dengan itu, Gerhard Kittel dalam buku Theological Dictionary Of The New Testament menjelaskan bahwa istilah $\lambda \alpha$ ós (laos) yaitu dimana di Korintus terdapat Komunitas Kristen atau di situ terdapat beberapa Kristen, orang-orang Kristen yang akan datang. Ini berasal dari $\epsilon \theta \nu \eta$ (ethne) yang mana Paulus seperti biasa harus beralih sejak bangsa Yahudi menolaknya.

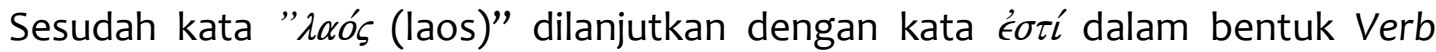
Indicative Present Active-third person Singular adalah perbuatan yang benar-benar dilakukan dan yang aktif dilakukan secara terus menerus orang ketiga tunggal, dari kata dasar eíuí yang artinya ada, adalah, berada, terdapat, tinggal, terjadi, menjadi, mungkin, melambangkan, sama seperti, artinya, yaitu. Ditulis sebanyak 2461 kali. Kata

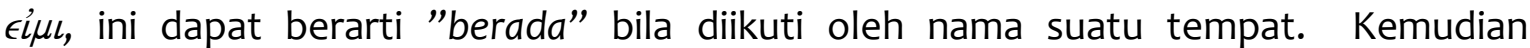
dilanjutkan dengan kata $\mu o \iota$ pronoun personal dative singular from $\dot{\epsilon} \gamma \dot{\omega}$, Kata '́ $\gamma \omega$ mengacu kepada (objek tak langsung) pribadi Tuhan Allah sendiri yang menyampaikan perintah atau pesan. Maka dapat disimpulkan kata "umat-Ku" menunjukkan bahwa terdapat atau ada orang-orang yang masih hidup di dalam Tuhan, orang-orang yang percaya kepada Tuhan yang berada di tempat pelayanannya. Dan yang akan mendukung dan turut di dalam pelayanannya.

\section{Faktor Penyebab Problematika Penginjilan Di Gkpa Se-Resort Padang sidimpuan Tenggara}

Pemimpin kurang memiliki visi dan misi

Menjadi efektif dan berhasil adalah impian setiap orang yang menjadi pemimpin. Maka proses demi proses dilalui dan pada akhirnya kepemimpinan dari seorang pemimpin berhasil. Nabi Yesaya pernah mengingatkan tugas dan visi untuk misi sedunia kepada rakyat Israel (Yes. 49:6). Paulus memiliki visi yang dari sorga dan juga semangat yang luar biasa untuk melaksanakan tugas misi dunia (Kis.I 26:19b). Tuhan juga memperlihatkan suatu penglihatan kepada rasul Yohanes di pulau Patmos. Yohanes melihat dua hal yaitu: pertama, pusat dari gereja dan alam semesta adalah takhta Allah dan Anak Domba; kedua, visi tentang perwujudan penginjilan dunia melalui gereja (Why. 7:9-12). Tanpa visi, perubahan itu sulit tercapai. Setelah itu, ia baru dapat mengembangkan strategi untuk mewujudkan visi.

Namun, pada masa kini dari penuturan Pdt.R. Siregar mengatakan bahwa "sebenarnya GKPA secara keseluruhan belum mempunyai visi dan misi. Saat ini GKPA sedang menyusun visi dan misinya sebagai dasar dalam perjalanan pelayanannya di tengah dunia ini. Namun, GKPA mempunyai Tema dan Sub Tema yang ditetapkan setiap lima tahun (1 periode). Yang menjadi Tema GKPA tahun 2011-2016 adalah diambil dari Roma 1:16b"Injil adalah kekuatan Allah yang menyelamatkan setiap orang yang percaya" dan sebagai Sub Tema: "Dengan kekuatan Injil, warga GKPA menjadi pembawa kelepasan, keteduhan dan kedamaian dalam mengemban tugas panggilan 
gereja". Semua program pelayanan GKPA yang disusun dalam Pokok-pokok Tugas Panggilan Gereja (PTPB) diarahkan kepada satu tema ini dalam jangka 5 tahun".

\section{Kurang memiliki program pelayanan penginjilan}

Menurut Boeker, meskipun seorang gembala tidak terlibat langsung dalam penginjilan, namun tugas pokoknya adalah membuat program penginjilan dengan memiliki visi - misi yang jelas dan mengajarkan kepada jemaat tentang penginjilan disertai dengan metode penginjilan Pemimpin di satu gereja hanya mengikuti program pelayanan yang telah ditetapkan oleh sinode atau kantor Pusat GKPA. Seperti yang diutarakan oleh Pdt. R.S bahwa bagigereja GKPA penginjilan belum mendapat penekanan dengan baik. Program tahunan gereja belum menyentuh kepada penginjilan. Penginjilan dirasakan masih asing dan tidak perlu untuk dilaksanakan sehingga penginjilan tidak menjadi bagian program gereja. Umumnya program gereja masih terfokus hanya kepada pelayanan di dalamsaja. Maka dengan demikian pelayanan yang dilakukan yang secara rutin dilakukan untuk melayani umat Tuhan di wilayah resort Padangsidimpuan Tenggara.

\section{Kurang menjadi penggerak / Motor pelayanan misi penginjilan}

Selain dari pada itu, menurut Yakob Tomatala pemimpin itu harus memobilisasi seluruh komponen anggota jemaat terlibat dalam semua aspek pelayanan gereja guna "memuridkan orang berdosa" menjadi milik Tuhan Yesus Kristus. Dan melengkapi semua anggota gereja dengan pengetahuan dan kecakapan untuk melayani dengan menyiapkan bentuk-bentuk pelatihan yang tepat guna bagi semua anggota berdasarkan karunia rohani yang ada pada setiap mereka.

Akan tetapi, Pdt. R.S. mengatakan bahwa "Kurangnya kesadaran pimpinan akan pentingnya PI bagi gereja. Pimpinan GKPA sering terpaku hanya kepada program tahunan GKPA sementara program tahunan GKPA sangat minim menyinggung misi $\mathrm{PI}$, padahal pimpinan GKPA bisa saja bertindak aktif terhadap PI walaupun tidak diprogramkan dalam tahun yang bersangkutan. Sehingga pelayanan yang dikerjakan hanya untuk mencapai program pelayanan yang telah dicanangkan.

\section{Jemaat kurang memberi dana}

Alkitab penuh dengan petunjuk-petunjuk tentang memberi. Misalkan, Salomo mengajarkan: "Muliakanlah TUHAN dengan hartamu dan dengan hasil pertama dari segala penghasilan" (Ams. 3:9). Paulus memberi tahu jemaat di Korintus tentang hal memberi uang (1Kor. 16:1-2). Lalu Paulus juga menulis kembali kepada mereka bahwa memberi dengan kerelaan hati (2Kor. 9:7). Umat belum memiliki hati untuk mendukung pelayanan penginjilan." Maka dengan demikian dengan kondisi umat yang belum memiliki hati maka firman Tuhan terkhusus berbicara misi dan hal memberi belum dapat diaplikasikan dalam kehidupan sehari.

\section{Jemaat kurang beriman dan berdoa}

David Beer berpendapat bahwa "doa adalah jantung kehidupan gereja dalam Kisah Para Rasul. Doa mendemonstrasikan ketergantungan kita kepada Allah. Namun, hal ini kurang diperhatikan oleh umat Tuhan sekarang ini khususnya di jemaat GKPA seresort Padang sidimpuan Tenggara. Salah satu contoh dari H.N salah satu majelis/sintua GKPA di Resort Padangsidimpuan Tenggara mengatakan bahwa ia 
kurang berdoa ataupun kurang percaya akan kuasa Firman di dalam penginjilan. la mengatakan penginjilan tidak dapat terlaksana oleh karena kurang percaya dan tidak berani terhadap orang muslim. Dan tidak dapat sepenuhnya percaya bahwa Allah akan menolong pada waktu penginjilan. Keragu-raguan membuat tidak terlaksananya penginjilan di tempat tinggal dan di sekitarnya.

\section{Pemahaman tentang Firman Tuhan yang terbatas}

Banyak orang yang tidak mengatakan suatu apapun, sebab tidak punya apa yang akan dikatakannya. Dan sebabnya tidak punya apa yang akan dikatakan, karena tidak mendengarkan firman Allah. Maka, penginjilan akan semakin sulit apabila tidak mengerti dan tidak tahu firman Tuhan.

Ibu S mengatakan bahwa kurang memahami firman Allah sehingga tidak ada yang membuat ibu tersebut untuk memiliki kerinduan melaksanakan penginjilan bagi orang yang disekitarnya. Dan ibu tersebut juga tidak tahu apa yang harus disampaikan kepada orang lain. Penginjilan tidak terlaksana jika tidak memiliki pengetahuan ataupun tidak tahu untuk menyampaikan Injil. Sama halnya yang dialami seorang bapak yang bernama H.N mengatakan bahwa "banyak jemaat GKPA yang belum memiliki pengetahuan akan firman Allah terkhusus mengenai Amanat Agung.

Jadi, kurang mengetahui akan firman Allah sangat berdampak khusus bagi penginjilan dan pertumbuhan iman juga pasti kurang baik.

\section{Kurangnya pengajaran misi penginjilan} bahwa:

Ronald dalam bukunya yang berjudul melayani dengan efektif mengatakan

Pengajaran membentuk dasar logis bagi setiap kegiatan lainnya yang membentuk kehidupan gereja setempat. Pengajaran masuk ke dalam unsur penginjilan, ibadah, persekutuan, pelayanan, doa, dan disiplinKalau tak ada pengajaran, bagaimana kita bisa mengetahui pesan apa yang harus diberikan kepada yang tersesat dan bagaimana kita melaksanakan penginjilan? Kalau tak ada pengajaran, bagaimana kita tahu siapa yang harus disembah, dan bagaimana kita menyembahnya? Kalau tak ada pengajaran, bagaimana kita tahu apakah persekutuan yang sebenarnya itu, bagaimana melaksanakan pelayanan, bagaimana bersoa dan apa yang harus didoakan, dan kepada siapa dan bagaimana kita melaksanakan disiplin? Secara logis pengajaran mendahului segala unsur lainnya.

Jadi, pengajaran merupakan unsur yang sangat mendasar bagi unsur yang lainnya dengan kata lain mendahului atau pengajaran harus muncul pertama kali. Pengajaran dapat dilakukan baik secara verbal maupun non-verbal. Namun masih belum kelihatan hasil yang dapat dirasakan di dalam gereja GKPA oleh karena, sebagai berikut:

\section{Konsep Penginjilan Dalam Kisah Para Rasul 18:9-10 Dapat Merevitalisasi Penginjilan Di Gkpa Se-Resort Padangsidimpuan Tenggara}

\section{Pentingnya panggilan}

Perjumpaan Saulus dengan Tuhan Yesus merupakan perjumpaan yang Ilahi.Melalui perjumpaan tersebut, telah mengubah segala-galanya di dalam diri Saulus, baik pendiriannya, konsepnya terhadap kehendak Tuhan, bahkan juga menjadi 
panggilan bagi Saulus untuk melayani Tuhan Yesus. Perjumpaan Paulus dengan Yesus Kristus memulai hidup baru bagi Paulus. Perjumpaan dengan Yesus secara langsung meyakinkan nalar dan nuraninya tentang kenyataan kebangkitan-Nya.

Sama halnya dengan setiap orang percaya memiliki panggilan di dalam dirinya masing-masing yang bertujuan untuk memuliakan Tuhan dengan cara yang berbedabeda. Kisah panggilan Paulus begitu mengesankan dan menunjukkan di mana Tuhan yang berkuasa atas hidup manusia. Untuk itu sangat diperlukan panggilan untuk melayani Tuhan terutama panggilan untuk penginjilan bagi semua orang tanpa dibatasi tempat, budaya dan lain sebagainya. Panggilan untuk penginjilan penginjilan tidak hanya kepada hamba Tuhan saja tetapi kepada semua orang percaya kepada Kristus termasuk jemaat GKPA se-resort Padangsidimpuan Tenggara. Dengan mengenali dan memahami penggilan Tuhan bagi setiap orang percaya/jemaat maka akan memikirkan bagaimana Injil dapat disampaikan kepada semua orang tanpa terkecuali, karena Injil dibutuhkan oleh semua orang.

\section{Jangan takut}

Tuhan memberi penguatan kepada Paulus untuk tidak takut terhadap orangorang Yahudi, kepala penguasa dari sinagoge, hakim-hakim di kota Korintus, oleh karena mereka tidak memiliki daya untuk melawan Paulus. Sekalipun perkataan mereka dan penampilan mereka yang mencemaskan hati Paulus, Tuhan mengatakan kepadanya jangan takut. Jangan takut kepada apapun kecuali Allah, akan tetapi kenyataannya manusia tidak takut akan Allah, sebaliknya sangat takut kepada hal-hal lain. Hal ini adalah dosa menghina Allah dan dosa yang membawa ke dalam kebinasaan di neraka. (Why.21:8).

Hamba Tuhan dan jemaat Tuhan di GKPA se-resort Padangsidimpuan Tenggara juga tentunya pasti diberi perintah, penguatan dan penghiburan yang sama besarnya. Jangan takut bukan hanya perintah ditujukan kepada Paulus saja melainkan kepada semua orang percaya yang mau melaksanakan penginjilan dengan segenap hati. Jangan merasa tenteram dengan sikap yang berdiam diri tetapi hendaknya hamba Tuhan dan Jemaat Tuhan tetap menjadi seorang duta besarnya Kristus. Sekalipun banyak menghadapi tantangan dari orang lainnya. Tuhan menginginkan Paulus, hamba Tuhan dan jemaat berhenti merasa takut atau dengan kata lain diperintahkan atau didorong untuk menghentikan rasa takut itu dan kembali untuk melaksanakan tugas dan tanggung jawabnya sebagaimana mestinya di dalam pemberitaan Firman/Injil.

\section{Teruslah memberitakan Injil}

Menurut Alfred dalam bukunya yang berjudul penginjilan pribadi mengatakan bahwa:

Orang - orang Kristen yang tidak pergi memberitakan Injil akan segera punah. Demikian juga sidang Jemaat yang sudah tidak punya jiwa penginjilan, dan yang berdiam diri dengan merasa puas telah jadi "gudang kebenaran", akan segera lenyap pula. Dahulu jemaat Yerusalem dikejar-kejar, maka mereka jadi tersebar, dan segala anggotanya lalu jadi penginjil (Kis. 11:19).

Maka, penjelasan di atas memberikan motivasi untuk tetap dalam memberitakan Injil seperti yang dikehendaki Allah bagi setiap orang percaya. Dan setiap orang Kristen (pendeta dan jemaat) dapat memikirkan dan membuat target atau sasaran agar di dalam memberitakan Injil memiliki fokus dan arah yang tepat. 
Rasul Paulus memiliki sasaran pemberitaannya/penginjilan yaitu orang-orang Yahudi dan Non-Yahudi (Kis. 18:8; lihat juga 1Kor. 1:12). Sehingga dengan sasaran tersebut Paulus dapat melayani mereka dengan efektif dan mempelajari kehidupan orang-orang tersebut. Yakob Tomatala mengemukakan dalam bukunya teologi misi bahwa "sasaran utama penginjilan ialah orang yang belum mendengar Injil atau orang yang belum memiliki kepastian keselamatan dari TUHAN Yesus. Apabila suatu jemaat memfokuskan pelayanan pekabaran Injil kepada sasaran dimaksud maka ada pertumbuhan gereja.

\section{Perlu mencapai sasaran gereja}

Alkitab menandaskan bahwa Injil harus disampaikan kepada semua orang mulai dari dalam gereja (Mat. 28:19-20; 25:14; Kis. 1:8). Diharapkan bahwa dapat dipastikan semua anggota jemaat secara pribadi memiliki hubungan pribadi dengan Yesus Kristus sebagai TUHAN dan Juruselamat. Yakob Tomatala menjelaskan sasaran internal gereja yang ingin dicapai melalui penginjilan dijabarkan secara rinci untuk menjelaskan tentang siapa saja yang patut diinjili:

1. Dalam kenyataan, ada orang Kristen yang sungguh memahami Injil, mereka terbukti telah menerima Yesus Kristus sebagai Tuhan dan Juruselamat, serta berkembang dalam iman, menjadi anggota suatu jemaat lokal, kemudian membuktikan diri sebagai setia bergereja. Orang-orang Kristen pada kategori ini perlu mendengar Injil demi peneguhan iman mereka saja.

2. Ada pula orang Kristen yang telah menjadi anggota gereja, tetapi mereka tidak setia bergereja. Kelompok orang Kristen seperti ini sangat perlu mendengar Injil untuk memperoleh kepastian keselamatan, karena ada kecenderungan mereka belum memiliki hubungan pribadi dengan Yesus Kristus sebagai Juruselamat, sehingga mereka tidak memahami makna yang hakiki dari kehidupan sebagai umat Allah yang sejati.

Dengan demikian, isi berita Kabar Baik diperlukan setiap manusia di dunia ini, sehingga penginjilan begitu sangat perlu dilaksanakan oleh jemaat di gereja GKPA seresort Padangsidimpuan Tenggara dan pada akhirnya memuliakan Tuhan.

\section{Jangan berdiam diri sebab Tuhan menyertai}

Paulus diperintahkan oleh Tuhan agar tidak mempertahankan rasa nyamannya di dalam berdiam diri melainkan Paulus harus kembali melaksanakan pelayanannya yang selama ini ia lakukan yakni pemberitaan Injil/penginjilan. Walaupun situasi dan kondisi tidak mendukung pelayanan namun Injil harus disampaikan bagi semua orang. Demikian juga dengan gereja GKPA se-resort Padangsidimpuan Tenggara sudah seharusnya belajar meneladani pelayanan Paulus dimana gereja harus tetap memberitakan Injil sekalipun ada banyak tantangan, hambatan-hambatan dan bahkan ancaman namun firman Tuhan menjadi penopang dan yang menguatkan untuk memberitakan Injil di dalam pelayanan dan kehidupan sehari-hari. Setiap orang Kristen sudah seharusnya menjadi duta Kristus bagi dunia untuk memperkenalkan dan atau memproklamirkan Injil di tempat ia berada.

Penguatan yang dari Tuhan membuat Paulus kembali bersemangat dan dengan janji yang Tuhan berikan kepadanya bahwa Tuhan bersama dengan Paulus dengan kata lain Tuhan turut campur tangan di dalam pelayanannya sehingga pelayanan tersebut 
menghasilkan buah yang diberkati Tuhan. Janji yang sama juga tentunya diperuntukkan bagi gereja masa kini khususnya GKPA se-resort Padangsidimpuan Tenggara jika gereja memiliki kesungguhan melaksanakan penginjilan. Kekuatan manusia tidak akan sanggup untuk mengatasi masalah, namun bersama Tuhan masalah apapun pasti terselesaikan dengan baik oleh karena itu tidak ada yang mustahil bagi Tuhan. Penginjilan di daerah yang sulit pun pasti dapat dilaksanakan oleh karena Tuhan yang akan memampukan setiap orang percaya.

\section{Tidak ada seorang pun yang akan menjamah dan menganiaya engkau,}

Di dalam pemberitaan Injil yang dilakukan Paulus tentu ada yang tidak suka seperti orang-orang Yahudi, orang Yunani, dan pemerintahan pada waktu itu. Banyak hujatan, ancaman bahkan berniat untuk mencelakakan diri Paulus. Tetapi jika Tuhan berfirman maka tidak akan terjadi dan bahkan sebaliknya akan semakin banyak orang percaya kepada Tuhan. Untuk itu, gereja GKPA se-resort Padangsidimpuan tidak perlu terlalu mengkhawatirkan siapapun yang berniat untuk menghambat atau menghalangi pemberitaan Injil oleh karena Tuhan turut campur tangan di dalam pemberitaan Injil. Tantangan dan hambatan tentu ada di dalam penginjilan namun satu hal yang pasti untuk menguatkan orang percaya yaitu siapapun orangnya dan sehebat apapun orang tersebut yang berniat untuk menghambat penginjilan tidak akan sanggup membendung kemahakuasaan Tuhan di dalam penginjilan atau pemenangan jiwa-jiwa.

\section{Kesimpulan}

Dari pokok pembahasan di atas, maka penulis menyimpulkan bahwa orang Kristen jemaat GKPA se-resort Padangsidimpuan Tenggara harus dapat memahami strategi penginjilan dan pelaksanaan penginjilan itu sendiri bagi gereja GKPA se-resort Padangsidimpuan Tenggara. Orang Kristen harus menyadari bahwa penginjilan merupakan tugas yang sangat penting selaku pengikut Kristus di tengah-tengah dunia yang tidak bersahabat ini.

Untuk itu sangat diperlukan pengajaran dan pembimbingan firman Allah di dalam kehidupan orang Kristen, karena dengan memiliki pengetahuan tentang firman Allah yang benar dan kuat maka jemaat atau orang Kristen tidak akan mudah tersesat dan tidak akan mudah goyah imannya. Bahkan dapat melaksanakan tugas dan tanggung jawabnya dihadapan Tuhan di dalam melakukan penginjilan.

Makna pernyataan dalam penglihatan dari Allah "Jangan takut! Teruslah memberitakan firman dan jangan diam! Sebab Aku menyertai engkau dan tidak ada seorang pun yang akan menjamah dan menganiaya engkau, sebab banyak umat-Ku di kota ini". Dimana Tuhan tidak pernah lalai atau membiarkan pelayan atau hamba Tuhan mengalami kesulitan di dalam menunaikan tugas dan tanggung jawab yang diberikan.

Dari Kisah Para Rasul 18:9-10 ini dapat diperhatikan terdapat ada tiga perintah dan juga ada tiga janji/jaminan di dalam pelaksanaannya, yaitu: tiga perintah (keinginan atau harapan) yang Tuhan sampaikan kepada Paulus yaitu pertama, jangan takut; kedua, teruslah memberitakan firman; ketiga, jangan diam. Dan tiga jaminan yang Tuhan nyatakan bagi Paulus yaitu pertama, sebab Aku menyertai engkau; kedua, tidak ada seorang pun atau tidak ada yang akan menyerangmu hingga menyakitimu; ketiga, sebab banyak umat-Ku di kota ini. Maka dengan demikian hal ini membuktikan bahwa Allah yang dilayani Paulus adalah Yesus Kristus yang berkuasa di sorga dan di bumi (dapat dilihat Matius 28: 18). 


\section{Kepustakaan}

\section{Buku}

Balz and Gerhard Schneider Horst,

1991 Exegetical Dictionary Of The New Testament, Vol 2, Michigan: Grand Rapids: William B. Eerdmans Publishing

Barker Kenneth,

1985 The New International Version, Study Bible (Grand Rapids, Michigan: Zonderwan, Publishing House

Balliet Emil, 1982 Kisah Para Rasul, Malang: Gandum Mas

Bastian Marpaung Adolv,

2014 Merajut Kerukunan Menuai Kedamaian, Medan: L - SAPA Pematangsiantar bekerjasama dengan Kantor Pusat GKPA

Beer David, 200650 Cara Membuat Gereja Anda Bertumbuh, Yogyakarta : ANDI

C. Tenney Merrill, 2001 Survei Perjanjian Baru, Malang: Gandum Mas

Den End Van, 2010

Harta Dalam Bejana, Jakarta: PT BPK Gunung Mulia

E. Ladd George, 2002 Theologia Perjanjian Baru II, Bandung: Kalam Hidup

F. F Bruce, 1999

Dokumen-Dokumen Perjanjian Baru, Jakarta: PT. BPK Gunung Mulia

F. Harrison Everett, 1986 Interpreting Acts; The Expanding Church, Grand Rapids, Michigan

F. Walker D, 1988 Kamus Singkat Yunani - Indonesia, Jakarta: BPK Gunung Mulia

Griffith Michael, 1991 Gereja Dan Panggilannya Dewasa Ini, (Jakarta: Gunung Mulia

H. Van Den Brink, 1989

Tafsiran Alkitab Kisah Para Rasul, Jakarta: BPK Gunung Mulia

Halim Makmur, $2000 \quad$ Misi Diskusi Dan Doa, Malang: Gandum Mas

I.H.Enklaar H.Berkhof, $2004 \quad$ Sejarah Gereja, Jakarta: Gunung Mulia

Johnston Philip, 2011

IVP Introduction to The BIBLE; Pengantar Untuk Mengenal Alkitab, Bandung: Yayasan Kalam Hidup

J. Williams David, 1990 New International Biblical Comentary: Act, Peabody, Maschusetts Publisher

K. Suawa Ferdinan, 2009

Memahami Gramatika Dasar Bahasa Yunani Koine, (Bandung: Yayasan Kalam Hidup 
Kittel Gerhard,

1972 Theological Dictionary of The New Testament, Volume VIII, Grand Rapids, Michigan: WM. B. Eerdmans Publishing Company,

M. Newman Jr Barclay

2005 Kamus Yunani-Indonesia untuk Perjanjian Baru, Jakarta: Gunung Mulia

Narbuko H. Achmadi Cholid,

$1997 \quad$ Metode Penelitian, Jakarta : Bumi Aksar

Natzir Muhamad,

$1988 \quad$ Metode Penelitian, (Jakarta: Ghalia Indonesia

Ronda Daniel,

2011 Leadership Wisdom, Antologi Hikmat Kepemimpinan, Bandung:

Yayasan Kalam Hidup,

Simanjuntak Alfred,

1990 Buku Makalah Seminar Pertumbuhan Gereja 1989, Jakarta: Panitia SPG

Sidlow Baxter J, 1988 Menggali Isi Alkitab, Jakarta: Yayasan Komunikasi Bina Kasih,

Sun Park Yune, 2001 Tafsiran Alkitab Kisah Para Rasul, Malang: Departemen Literatur YPPII

Th.van, Den, End \& J, Weitjens,

2011

Ragi Carita 2, Jakarta: PT BPK Gunung Mulia

Tulluan Ola,

1999 Introduksi Perjanjian Baru, Malang: Departemen Literatur YPPII

Vine W.E,

1952 Expository Dictionary Of New Testament Words, Grand Rapids, Michigan: Zondervan Publishing House

V. Wigram \& Ralph D. Winter Goerge,

The Word Study Concordance

W. Peters George,

2002

Teologi Pertumbuhan Gereja, Malang: Gandum Mas

\section{Internet}

- $\quad$ Http://Id.Wikipedia.Org/Wiki/Seminar, On line 23 Desember 2014

- $\quad$ http//www.oikoumene.org/en/member-churches/Christian-prostestant-angkolachurch, ON LINE, 20 Oktber 2014 